\title{
SFN and GapFillers: Challenges and solutions in the Distribution of Digital Signal
}

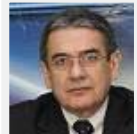

Moderator: PAULO ROBERTO MONFRIN CANNO

Director of Network Technology Gazette ES / SET

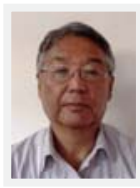

Testes em Multipercurso com SFN e Soluções de GapFillers Speaker: JULIO OMI

Visitor Professor at Digital TV Laboratory /

University Mackenzie (UPM).

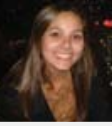

Inovações e desafios na utilização de Gapfillers na rede SFN

Speaker: ALINE DEGLI

Telecommunication Project Engineer / TV Globo

Mais de $\mathbf{2 0 0}$ cidades em SFN e as lições aprendidas Speaker: EWERTON MACIEL

Technology Director / TV TEM 


\title{
SFN and GapFillers: Challenges and solutions in the Distribution of Digital Signal
}

\author{
Moderator: Paulo Roberto Monfrin Canno \\ Director of Network Technology Gazette ES / SET
}

We will have the opportunity to share the experience of those who operate about 200 sites of SFN transmission, as well as the challenges and best practices in the gap-fillers deployment. In addition, advances in digital TV receivers will be presented: on the sensitivity, multipath, SFN and interference, compared with the first generations of ISDB-Tb receptors.

- Tests Multipath with SFN and GapFillers Solutions Speaker: Julio Omi Visitor Professor at Digital TV Laboratory / University Mackenzie (UPM).

Be presented studies and field tests concerning the subject.

- Innovations and challenges when using gap fillers in the SFN network Speaker: Aline Degli

Telecommunication Project Engineer / TV Globo

To meet the demand for innovation and the expansion of digital coverage at TV Globo, it has been necessary to enhance the installations of gap fillers in locations such as tunnels and the tops of buildings. The use of different polarizations, non-conventional receiver antennas and other techniques has proven fundamental for achieving the insulation the systems need and for guaranteeing the proper transmission power and good-quality coverage in the regions of interest.

- Over 200 cities on SFN and the lessons learned

Speaker: Ewerton Maciel

Technology Director / TV TEM

TVTEM has one of Brazil's largest SFN networks and, since 2008, it has faced the challenge of how to expand this network. The technology has come of age and, with the lessons learned over these years, we can assure viewers of the total quality of digital signals in over 200 cities with SFN.

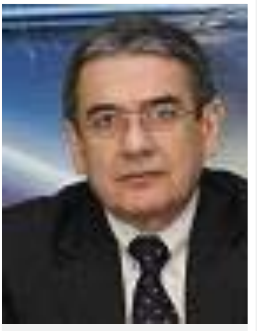

\section{PAULO ROBERTO MONFRIN CANNO}

Technology Director - Rede Gazeta Network ES/ SET

An Electrical Engineering graduate from the São Carlos School of Engineering of the University of São Paulo and a graduate degree in Enterprise Management from the FGV. He was involved in the design and installation of radio and TV transmission systems between 1976 and 1984, as the engineer in charge at Sociedade Nacional de Eletrônica. From 1984 to 1986 he worked at Engesa Eletrônica, where he was in charge of the component quality control laboratory.

He has been with Rede Gazeta in the State of Espírito Santo (a Globo Network affiliate) since 1986, where he is Technology Director with responsibility for the entire technology infrastructure that supports the group's television and radio broadcasters. 


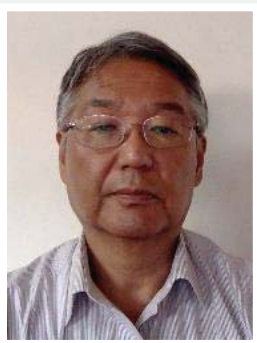

\section{JULIO OMI}

Visitor Professor at Digital TV Laboratory / University Mackenzie (UPM).

Graduated in electronic engineering from the Polytechnic School at USP, and has a Master's in Engineering from the University of Tokyo.

He was Engineering Manager of the Radio Department at NEC do Brasil, and took part in the ITU-R, in the TG-8/1 and WP-8F Groups handling the IMT-2000 systems, and also at CITEL. $\mathrm{He}$ was a member of the Brazilian delegation to the Radio Communication Conferences in 1995, 1997 and 2000.

Took part in work at the Digital TV Laboratory of Mackenzie University, on the SBTVD project. $\mathrm{He}$ is Visiting Professor at the Digital TV Laboratory of the Mackenzie Presbyterian University.

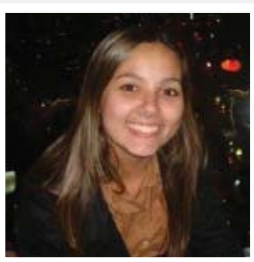

\section{ALINE DEGLI}

\section{Telecommunication Project Engineer / TV Globo}

PMP-PMI Certification in Project Management, MBA in Project Management -Getúlio Vargas Foundation, Undergraduate Degree in Telecommunications Engineering Fluminense Federal University. Professional Experience: Scaling and Management of projects for expanding Digital TV coverage, microwave links and operational communication the technology area of TV Globo.

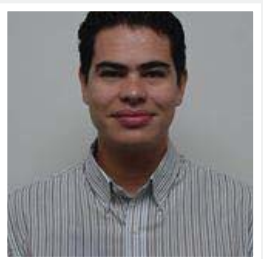

\section{EWERTON MACIEL}

Technology Director / TV TEM

Professional Project Manager (PMP) from the Getulio Vargas Foundation, Electrical Engineer, with the emphasis on Telecommunication for the Engineering School of Sorocaba, Electronics Technician from the Paula Souza Center, he has several IT certifications (Linux LPI, Microsoft MCSA, FPGA Programming). Professional Experience - Aramar Navy Technology Center, TV Globo, Harris Corporation and TV TEM, a TV Globo Affiliate, where he is currently Technology Director 